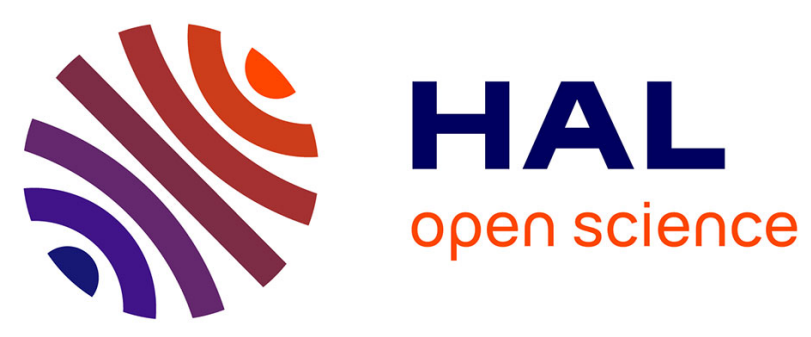

\title{
Early evolution of plasma soluble TNF-alpha p75 receptor as a marker of progression in treated HIV-infected patients.
}

\author{
Philippe Morlat, Edwidge Pereira, Pascal Clayette, Nathalie \\ Derreudre-Bosquet, Jean-Luc Ecobichon, Olivier Benveniste, Marianne Saves, \\ Catherine Leport
}

\section{To cite this version:}

Philippe Morlat, Edwidge Pereira, Pascal Clayette, Nathalie Derreudre-Bosquet, Jean-Luc Ecobichon, et al.. Early evolution of plasma soluble TNF-alpha p75 receptor as a marker of progression in treated HIV-infected patients.. AIDS Research and Human Retroviruses, 2008, 24 (11), pp.1383-9. 10.1089/aid.2007.0293 . inserm-00350155

\section{HAL Id: inserm-00350155 https://www.hal.inserm.fr/inserm-00350155}

Submitted on 6 Jan 2009

HAL is a multi-disciplinary open access archive for the deposit and dissemination of scientific research documents, whether they are published or not. The documents may come from teaching and research institutions in France or abroad, or from public or private research centers.
L'archive ouverte pluridisciplinaire HAL, est destinée au dépôt et à la diffusion de documents scientifiques de niveau recherche, publiés ou non, émanant des établissements d'enseignement et de recherche français ou étrangers, des laboratoires publics ou privés. 


\title{
Early Evolution of Plasma Soluble TNF- $\alpha$ p75 Receptor as a Marker of Progression in Treated HIV-Infected Patients
}

\author{
P. Morlat, ${ }^{1,2}$ E. Pereira, ${ }^{2}$ P. Clayette ${ }^{3}$ N. Derreudre-Bosquet ${ }^{3}$ J-L. Ecobichon, ${ }^{4}$ O. Benveniste,${ }^{5}$ \\ M. Saves, ${ }^{2}$ C. Leport, ${ }^{4}$ and the ANRS CO8 Aproco-Copilote Study Group ${ }^{*}$
}

\begin{abstract}
We evaluated the prognostic value of different mediators of inflammation: TNF- $\alpha$ and its soluble receptor p75, platelet-activating factor, and glutathione tripeptide in a case-control study nested within a cohort of 1281 patients infected by the human immunodeficiency virus (HIV) started on highly active antiretroviral treatment (HAART). During the first year of HAART, 16 cases experienced an AIDS-defining event and 6 experienced an evolution of $\mathrm{T} \mathrm{CD} 4^{+}$cell count $<100 / \mathrm{mm}^{3}$. Forty-four controls who did not progress during the same followup period were matched for age, baseline $\mathrm{CD} 4^{+}$, and HIV-RNA. In the control group, plasma levels of TNF- $\alpha$ and its soluble receptor p75 decreased significantly from baseline to month 4: from 11.0 to $8.7 \mathrm{pg} / \mathrm{ml}(p<0.001)$ and from 27.3 to $22.8 \mathrm{pg} / \mathrm{ml}(p<0.003)$, respectively. Furthermore the decrease of TNF- $\alpha$ and its soluble receptor p75 was larger in nonprogressors than in progressors $(p=0.003)$. Measurement of TNF- $\alpha$ soluble receptor p75 may be of interest as an additional marker of early antiretroviral effect.
\end{abstract}

\section{Introduction}

$\mathrm{T}$ HE CHRONIC IMMUNE ACTIVATION SPECIFIC TO HIV DISEASE contributes to HIV disease pathogenesis. Several cohorts have already shown the prognostic value of plasma levels of tumor necrosis factor- $\alpha$ (TNF- $\alpha$ ) and especially of its soluble TNF- $\alpha$ p75 receptor (sR-TNF- $\alpha$ p75) for HIV disease progression. ${ }^{1-7}$ These studies were mainly conducted before the era of highly active antiretroviral therapy (HAART) and information is lacking on the relationship between sR-TNF- $\alpha$ p75 or other immune markers with clinical progression in patients receiving HAART. In a previous study, we showed a correlation between the evolution of plasma levels of immune markers, especially sR-TNF- $\alpha$ p75, and simultaneous immunovirological responses in HAART-treated patients. However, this study did not assess the prognostic role of early variations of these markers on HIV disease progression. ${ }^{8}$

In addition, the prognostic role of other inflammatory mediators remains currently unknown. The platelet-activating factor (PAF; 1-O-alkyl-2-acetyl-sn-glyceryl-3-phosphorylcholine) may play a role in inflammatory and immune responses ${ }^{9}$ and some of its antagonists had in vitro antiretroviral properties. ${ }^{10,11}$ Inflammatory processes triggered by PAF are mediated by interactions with a specific PAF receptor $^{12}$ and restrained by a enzymatic PAF-inactivating system, including plasma PAF acetylhydrolases (PAF-AH) that catalyzes the hydrolysis of the $s n-2$ ester bond of PAF. ${ }^{13}$ Because PAF-AH is important for regulation of plasma PAF concentration, the dosage of plasma PAF activity is considered more reliable than PAF. Oxidative stress may also contribute to inflammatory processes in HIV disease and may be measured either by the major antioxidant in the organism, the glutathione tripeptide (GSH or L- $\gamma$-glutamyl-L-cysteinylglycine), ${ }^{14}$ whose low level is associated with poor survival in HIV-infected patients, ${ }^{15}$ or the activity of GSH peroxidases (GSH-Px), which oxidizes GSH in its disulfide form (GSSG). GSH-Px associated with superoxide dismutases (SOD) is an important initial component in cellular defenses against reactive oxygen species (ROS) toxicity, e.g.,

${ }^{1}$ CHU Bordeaux, 33075 Bordeaux, France and Université Victor Segalen Bordeaux 2, 33076 Bordeaux, France.

${ }^{2}$ INSERM, U593, 33076 Bordeaux, France and Institut de Santé Publique, d'Epidémiologie et de Développement, Université Victor Segalen Bordeaux 2, 33076 Bordeaux, France.

${ }^{3}$ Laboratoire de Neurovirologie, SPI-BIO CEA, 92265 Fontenay aux Roses Cedex, France.

${ }^{4}$ Assistance Publique-Hôpitaux de Paris, Hôpital Bichat and Université Paris 07 Denis Diderot, 75018 Paris, France.

${ }^{5}$ Assistance Publique-Hôpitaux de Paris, Hôpital Pitié-Salpêtrière and UMPC Université Paris 06, 75013 Paris, France.

*Members of the ANRS CO8 APROCO-COPILOTE Study Group are listed in the Appendix. 
superoxide anions $\left(\mathrm{O}_{2}{ }^{\circ-}\right)$ and hydrogen peroxide $\left(\mathrm{H}_{2} \mathrm{O}_{2}\right)$. Moreover, $\mathrm{HIV}$, by subverting the intracellular cysteine pool for its own replication, is able to decrease GSH biosynthe$\operatorname{sis}^{16}$ and to generate a production of inflammatory mediators such as TNF- $\alpha .{ }^{17}$

In the context of the well-validated surrogacy value of $\mathrm{CD} 4{ }^{+}$lymphocyte count and plasma HIV-RNA levels, which are the cornerstones of the laboratory follow-up in HIV-infected treated patients, we assessed the potential additive prognostic value of plasma levels of TNF, sR-TNF- $\alpha$ p75, PAF-AH, GSH, and GSH-Px on the progression of HIV infection in HAART-treated patients.

\section{Materials and Methods}

The study was a case-control study nested within the APROCO-COPILOTE cohort. This cohort is a prospective study of the French National Agency for Research on AIDS and viral hepatitis (ANRS CO8) that enrolled consecutively adult HIV-infected patients who for the first time started a protease inhibitor (PI)-containing regimen in 1997-1998 and were followed in 47 French clinical wards. ${ }^{18}$ Standardized clinical and biological data are collected at baseline, 1 and 4 months after enrolment, and every 4 months thereafter. Investigators are requested to report clinical progression and deaths to the coordinating center as soon as they are known. In the current analysis, cases (i.e., rapid progressors) were defined as patients who experienced HIV disease progression during the first year of treatment. Disease progression was defined as an occurrence of a new AIDS-defining event according to the CDC definition ${ }^{19}$ or a $\mathrm{T} \mathrm{CD} 4^{+}$cell count decline below $100 / \mathrm{mm}^{3}$ (two repeated measurements). Two control subjects (i.e., nonprogressors) per case were matched for age ( \pm 5 years), baseline $\mathrm{T} \mathrm{CD} 4^{+}$cell count $\left( \pm 80 / \mathrm{mm}^{3}\right)$, and plasma HIV-1 RNA $\left( \pm 0.3 \log _{10}\right.$ copies $\left./ \mathrm{ml}\right)$; these patients did not experience any clinical or biological progression as defined previously during their first year of HAART. All eligible cases and controls were selected if they had available plasma frozen at inclusion, at month 1 (M1), and at month 4 (M4) follow-up visits.

\section{Measurement of virological and immunological parameters}

$\mathrm{CD}^{+}$counts were measured by flow cytometry and plasma HIV-1 RNA levels were assessed using the local available assays, mainly bDNA Chiron 2.0 (detection threshold of 500 copies / $\mathrm{ml}$ or $2.7 \log _{10}$ copies $/ \mathrm{ml}$ ) or PCR by Amplicor-Roche (detection threshold of 200 copies $/ \mathrm{ml}$ or 2.3 $\log _{10}$ copies $\left./ \mathrm{ml}\right)$.

Plasma concentrations of TNF- $\alpha$ and its soluble p75 receptor were measured using specific R\&D Systems ELISA (Nivelles, Belgium), whereas plasma PAF-AH activity and plasma GSH and GSH-Px levels were quantified using Cayman Chemical assays (Ann Arbor, MI). These dosages were used according to the manufacturer's recommendations.

\section{Statistical analysis}

Comparisons between progressors and nonprogressors were performed by a Chi-square test for proportions and by a Wilcoxon test for median values. Evolution of immune markers was studied between baseline and M4 using a multivariate linear mixed model making it possible to test for ef- fect of time and of disease progression. Models were adjusted for age, history of AIDS, and baseline CD4 ${ }^{+}$cell count, plasma HIV RNA level, and hemoglobin. Before entering the values of immune markers in the model, they were $\log _{e}$ transformed to normalize the distribution. Analyses were performed using the Statistical Analysis System Software (version 8.2, SAS Institute, Cary, NC).

\section{Results}

\section{Study population and baseline characteristics}

Among the 26 patients of the APROCO-COPILOTE cohort who had clinical or laboratory progression during the first year of follow-up, 22 had a complete collection of frozen blood samples (baseline, M1, and M4) and were retained in the analysis as cases: 16 had experienced at least one clinical AIDS-defining event (Table 1) and 6 experienced biological progression only (the lowest levels of CD4 ${ }^{+}$lymphocyte count experienced by these patients were 19, 21, 65, 82, 69, and $54 / \mathrm{mm}^{3}$ ). Among the 22 progressors, 8 progressed early (between M1 and M4) and 14 progressed later (between M4 and M12). Forty-four nonprogressors were appropriately matched for age, baseline $\mathrm{CD}^{+}$cell count, and plasma HIV1 RNA.

On average, patients were 36 years old and were mainly infected through sexual contacts (Table 2). The median CD4 ${ }^{+}$ cell count was $120 / \mathrm{mm}^{3}$ and HIV-1 RNA $4.5 \log _{10}$ copies $/ \mathrm{ml}$. Progressors and nonprogressors differed only for median baseline hemoglobin level, 12.1 vs. $13.8 \mathrm{~g} / \mathrm{dl}$, respectively $(p=0.02)$.

\section{Evolution of laboratory markers during the first 4 months of $H A A R T$}

CD4+ Iymphocyte count. From baseline to M1 and M4, median CD4 ${ }^{+}$lymphocyte count increased from 125 to 201 (at M1) and $197 / \mathrm{mm}^{3}$ (at M4) in nonprogressors $\left(p<10^{-4}\right)$ but only from 113 to 148 (at M1) and $151 / \mathrm{mm}^{3}$ (at M4) in those patients who rapidly progressed ( $p=0.22$, NS).

Plasma HIV-1 RNA. During the same follow-up period, median plasma HIV-1 RNA level decreased from 4.6 to 2.7 in nonprogressors $\left(p<10^{-3}\right)$ and from 4.5 to $2.5 \log _{10}$

Table 1. Clinical Events Occurring during the First Year of Highly Active Antiretroviral Therapy in 22 CASES, ANRS CO8 APROCO-COPILOTE

Description of event Number of patients

Cytomegalovirus retinitis 3

Kaposi sarcoma 3

Non-Hodgkin lymphoma

Pneumocystis carinii pneumonia 2

Toxoplasmic encephalitis

Progressive multifocal

leukoencephalopathy

HIV encephalitis

Pulmonary tuberculosis

Esophageal candidiasis +

disseminated tuberculosis

Cerebral nocardiosis

3
3
2
2
1
1
1
1
1
1


Table 2. Baseline Characteristics of Cases and Controls Included IN THE ANAlysis, ANRS CO8 APROCO-COPILOTE

\begin{tabular}{lcc}
\hline & $\begin{array}{c}\text { Cases } \\
\text { Progression within } \\
\text { the first year of } \\
\text { HAART } \\
(\mathrm{n}=22)\end{array}$ & $\begin{array}{c}\text { Controls } \\
\text { Nonprogression } \\
\text { within the first year of } \\
\text { HAART } \\
(\mathrm{n}=44)\end{array}$ \\
\hline Median age in years (range) & $35.1(28.2-40.7)$ & $37.7(33.0-40.5)$ \\
HIV transmission category, $n(\%)$ & $9(40.9)$ & $14(31.8)$ \\
Heterosexuals & $8(36.4)$ & $17(38.6)$ \\
Men who have sex with men & $3(13.6)$ & $11(25.0)$ \\
Intravenous drug users & $2(9.1)$ & $2(4.6)$ \\
Other & $5(22.7)$ & $17(38.6)$ \\
CDC clinical stage, $n(\%)$ & $4(18.2)$ & $11(25.0)$ \\
A & $13(59.1)$ & $16(36.4)$ \\
B & $113(60-252)$ & $125(61-249)$ \\
C & $4.5(3.4-5.5)$ & $4.6(3.3-5.5)$ \\
Median CD4 ${ }^{+}$cells $/$mm $^{3}$ (range) & $12.1(10.1-13.8)$ & $13.8(11.9-15.1)$ \\
Median HIV1-RNA $\left(\log _{10}\right.$ copies/ml) (range) & 0.61 \\
Median plasma haemoglobin $(\mathrm{g} / \mathrm{dl})$ (range) & & 0.21 \\
\hline
\end{tabular}

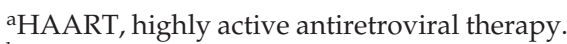

${ }^{\mathrm{b}} \mathrm{CDC}$, Centers for Disease Control.

copies $/ \mathrm{ml}$ in progressors $\left(p=3.10^{-4}\right)$; these decreases were not statistically different between the two groups $(p=0.32)$.

In nonprogressors, HIV-1 RNA reached undetectable levels (below $2.3 \log _{10}$ copies $/ \mathrm{ml}$ ) in 33\% at M1 and 45\% at M4 vs. $37 \%$ and $55 \%$ in progressors; these variations were not significantly different between the two groups $(p=0.8$ and $p=0.5$, respectively).

Plasma sR-TNF- $\alpha$ p75 and TNF- $\alpha$ levels. Among nonprogressors, median plasma sR-TNF- $\alpha$ p75 and TNF- $\alpha$ decreased significantly from baseline to M4: from 11.0 to 8.7 $\mathrm{pg} / \mathrm{ml}\left[-0.10 \log _{\mathrm{e}} \mathrm{pg} / \mathrm{ml} / \mathrm{month}\right.$ (adjusted $\left.\left.p<0.001\right)\right]$ and from 27.3 to $22.8 \mathrm{pg} / \mathrm{ml}\left[-0.06 \log _{\mathrm{e}} \mathrm{pg} / \mathrm{ml} / \mathrm{month}\right.$ (adjusted $p<0.003)]$, respectively (Table 3 and Fig. 1). Ajusted $p$-values of the variations between M0 and M4 did not change if undetectability of viral load at M4 was included as an additional variable in the models. Conversely, no significant decrease was observed in progressors $\left(-0.007 \quad \log _{\mathrm{e}}\right.$ $\mathrm{pg} / \mathrm{ml} / \mathrm{month}$ for sR-TNF- $\alpha$ p75 and $-0.04 \log _{\mathrm{e}} \mathrm{pg} / \mathrm{ml} /$ month for TNF- $\alpha$ ).

Among nonprogressors, median plasma sR-TNF- $\alpha$ p75 decreased significantly from baseline to M4 either in the 19 patients who achieved viral suppression at M4 or in the 25 who did not ( $p<0.001$ in both subgroups). Among progressors, no significant variation of plasma sR-TNF- $\alpha$ p75 was observed either in the 12 patients who achieved viral suppression at M4 or in the 10 who did not.

Finally, the decrease of plasma sR-TNF- $\alpha$ p75 between M0 and M4 was larger in nonprogressors than in progressors ( $p=0.003)$ but no significant difference was found for variations of TNF- $\alpha$ between the two groups (Table 3).

Between M0 and M1 we noticed that the median evolution of sR-TNF- $\alpha$ p75 was $-2 \mathrm{pg} / \mathrm{ml}$ in nonprogressors and + $0.5 \mathrm{pg} / \mathrm{ml}$ in progressors: the differences between these variations were also highly significant $(p=0.01)$. For TNF- $\alpha(-3$ $\mathrm{pg} / \mathrm{ml}$ in nonprogressors and $-1.8 \mathrm{pg} / \mathrm{ml}$ in progressors) no significant difference was found between the two groups.
Plasma GSH level. A significant increase of plasma GSH level was observed in nonprogressors from baseline to M4: $3.9-4.6 \mu \mathrm{mol} / \mathrm{ml}\left(+0.04 \log _{\mathrm{e}} \mu \mathrm{mol} / \mathrm{ml} /\right.$ month, adjusted $p=$ $0.008)$. No significant evolution was reported in progressors. Nevertheless, the overall evolution did not differ between patients who progressed and those who did not progress.

Between M0 and M1 we did not notice significant variations of median plasma GSH either in nonprogressors $(+0.5$ $\mu \mathrm{mol} / \mathrm{ml})$ or in progressors $(+1 \mu \mathrm{mol} / \mathrm{ml})$ and no significant difference was found between the two groups.

Plasma GSH-Px and PAF-AH levels. Plasma GSH-Px did not significantly change between baseline and M4, either in nonprogressors $(p=0.99)$ or progressors $(p=0.07)$. Similar trends were found for the evolution of plasma PAF-AH. No significant change within or between groups was observed between M0 and M1 for both markers.

\section{Discussion}

The decrease of plasma sR-TNF- $\alpha$ p75 was larger in nonprogressors than in progressors while the two groups were appropriately matched for baseline $\mathrm{CD}^{+}$lymphocyte count and plasma HIV-1 RNA and while differences of virological responses between groups did not explain the differences of HIV disease progression. As a result of our study design the sR-TNF- $\alpha$ p75 plasma level might be considered as a prognostic marker, in addition to baseline $\mathrm{CD}^{+}$and plasma HIV RNA in HAART-treated patients. Whereas the prognostic value of sR-TNF- $\alpha$ p75 plasma level variations within the first 4 months is obvious, the simultaneous variations of plasma HIV-RNA did not make it possible to predict HIV disease progression in our study.

If plasma levels of HIV-RNA and $\mathrm{CD}^{+}$cell count are highly predictive of progression to AIDS or death, they do not explain all the variability of disease progression. ${ }^{3,20,21} \mathrm{We}$ assume, as do others, that if an additional marker is required 
Table 3. Evolution of HiV-1 RNA and Immune Markers between Baseline and Month 4 in Cases (Progression during the First Year of Highly Active Antiretroviral Treatment) and Controls (Nonprogression), APROCO-COPILOTE ANRS CO8

\begin{tabular}{|c|c|c|c|}
\hline & $\begin{array}{l}\text { Progressor group } \\
\quad(\mathrm{n}=22)\end{array}$ & $\begin{array}{c}\text { Nonprogressor } \\
\text { group } \\
(\mathrm{n}=44)\end{array}$ & $\mathrm{p}^{\mathrm{a}}$ \\
\hline \multicolumn{4}{|c|}{ Median HIV-1 RNA $\log _{10}$ copies/ml) (range) } \\
\hline Baseline & $4.5(3.4-5.6)$ & $4.6(3.3-5.5)$ & 0.95 \\
\hline Month 1 & $2.7(2.5-3.8)$ & $2.7(2.6-3.1)$ & 0.64 \\
\hline Month 4 & $2.5(2.3-3.4)$ & $2.7(2.3-2.7)$ & 0.93 \\
\hline \multicolumn{4}{|c|}{ HIV RNA $<500$ copies $/ \mathrm{ml}, n(\%)$} \\
\hline Baseline & $3(13.6)$ & $2(4.6)$ & 0.32 \\
\hline Month 1 & $8(36.4)$ & $14(32.6)$ & 0.76 \\
\hline Month 4 & $12(54.6)$ & $19(45.2)$ & 0.48 \\
\hline \multicolumn{4}{|c|}{ Median sR-TNF- $\alpha$ p75 (pg/ml) (range) } \\
\hline Baseline & $14.1(8.3-20.3)$ & $11.0(7.5-22.4)$ & 0.73 \\
\hline Month 1 & $14.6(8.3-19.9)$ & $9.0(6.6-13.8)$ & 0.07 \\
\hline Month 4 & $11.5(6.1-20.3)$ & $8.7(5.9-11.5)$ & 0.05 \\
\hline \multicolumn{4}{|c|}{ Median TNF- $\alpha$ (pg/ml) (range) } \\
\hline Baseline & $35.7(20.0-44.5)$ & $27.3(19.9-42.3)$ & 0.53 \\
\hline Month 1 & $33.9(23.8-45.4)$ & $24.3(18.6-35.7)$ & 0.09 \\
\hline Month 4 & $28.7(18.6-37.8)$ & $22.8(18.4-29.2)$ & 0.12 \\
\hline \multicolumn{4}{|c|}{ Median PAF-AH $(\mu \mathrm{mol} / \mathrm{min} / \mathrm{ml})$ (range) } \\
\hline Baseline & $10.0(7.0-12.6)$ & $10.6(8.2-13.0)$ & 0.72 \\
\hline Month 1 & $11.8(7.7-14.0)$ & $10.3(7.4-12.6)$ & 0.21 \\
\hline Month 4 & $10.5(7.9-14.4)$ & $9.9(8.5-12.8)$ & 0.66 \\
\hline \multicolumn{4}{|c|}{ Median GHS ( $\mu \mathrm{mol} / \mathrm{ml})$ (range) } \\
\hline Baseline & $3.9(2.9-6.1)$ & $4.0(3.4-5.2)$ & 0.88 \\
\hline Month 1 & $4.9(3.4-6.7)$ & $4.5(3.1-6.1)$ & 0.63 \\
\hline Month 4 & $4.6(3.5-6.5)$ & $4.7(3.4-5.6)$ & 0.82 \\
\hline \multicolumn{4}{|c|}{ Median GHS-Px (ng/ml) (range) } \\
\hline Baseline & $604(471-729)$ & $652(546-800)$ & 0.37 \\
\hline Month 1 & $609(376-706)$ & $656(505-825)$ & 0.11 \\
\hline Month 4 & $642(430-728)$ & $700(568-788)$ & 0.33 \\
\hline
\end{tabular}

${ }^{\mathrm{a} C}$ Comparison between progressors and nonprogressors.

to predict more accurately HIV disease progression, the use of sR-TNF- $\alpha$ p75 might then be taken into account. ${ }^{22}$

Other inflammatory markers evaluated, i.e., TNF- $\alpha$, PAF$\mathrm{AH}, \mathrm{GSH}$, and GSH-Px levels, were not associated with disease progression. Although not established as having a prognostic value, the increase in GSH level in no progressing patients is nevertheless consistent with the deleterious effect of glutathione deficiency in progression of HIV disease. ${ }^{15,16}$

In our study, TNF- $\alpha$ plasma level was not associated with HIV disease progression. TNF- $\alpha$ itself may be difficult to detect in the circulation because of its rapid clearance and the use of assays unable to detect TNF bound to sR-TNF- $\alpha$ p75. ${ }^{23}$ In contrast, sR-TNF- $\alpha$ p75 is easily detectable in the plasma of HIV-infected patients and plasma sR-TNF- $\alpha$ p75 may be considered as a long-term marker of TNF effects. ${ }^{24,25}$

The limited size and the case-control design of our study comparing two groups matched for age, baseline CD4 ${ }^{+}$ count, and HIV-1 RNA restrict the interpretation of our results to the additive role of plasma immune markers to already well-known surrogate markers as we cannot make inferences regarding the intrinsic prognostic role of the markers. Other observational studies are necessary to confirm the prognostic role of sR-TNF- $\alpha$ p75 on disease progression under HAART and to reevaluate those of other inflammatory markers, particularly for components of the GSH system; these further evaluations could also be of value to assess if markers of immune status, such as CD8 T cell activation, are prognostic of the failure of HAART, which is still a controversial issue. ${ }^{26-28}$ During the chronic phase of HIV infection, particularly in progressors and even in patients undergoing HAART, the functionality of HIV-specific CD8 T cells is gradually altered, partly due to persistent antigenic stimulation and progressive loss of CD4 T cells. ${ }^{29}$ The TNF system, by its ability to interfere with HIV replication, apoptosis, and $\mathrm{T}$ cell activation, could play a major role in this functionality of CD8 $\mathrm{T}_{\text {cells }}{ }^{30}$ and the relationship between the TNF system and the activation status of CD8 T cells would then be particularly interesting to study. Concerning the GSH system, the depletion of GSH and GSH-PX in blood was confirmed during the acute infection of monkies by SHIV. ${ }^{31}$ Nevertheless, even if a correlation was observed between GSH in blood and lymphocyte proliferative responses in HIV-infected patients, this correlation is not associated with variations for HIV viral load and CD4 and CD8 counts. $^{32}$ Moreover, during chronic infection, no significant associations were found by Stephensen et al. ${ }^{33}$ between GSH and GSH-Px concentrations in blood and the severity of HIV disease. As a consequence, it seems difficult at present to consider these elements of the antioxidant defenses as markers of HAART failure. 


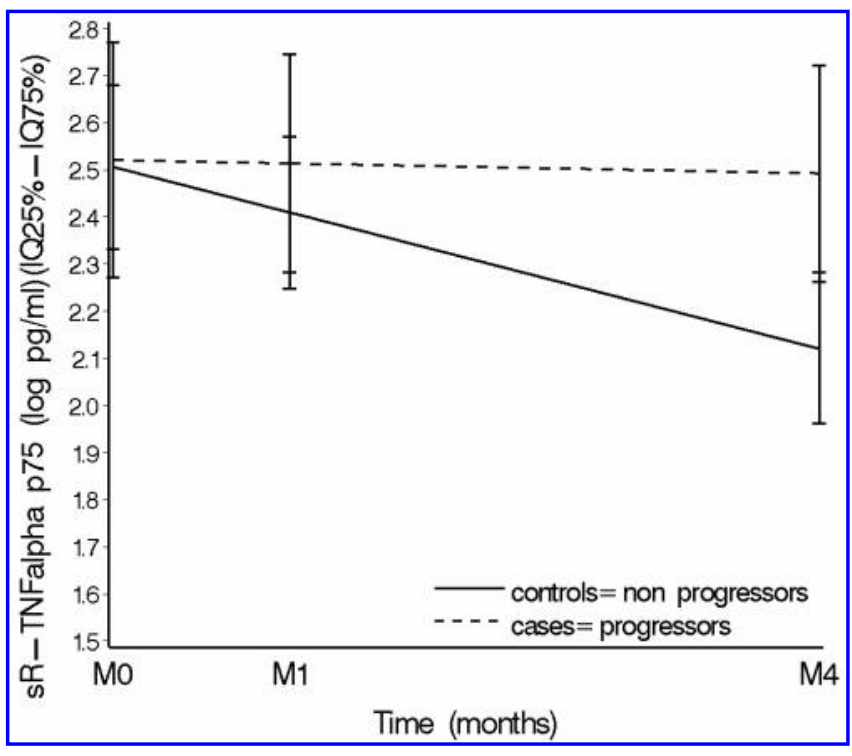

FIG. 1. Evolution of plasma sR-TNF $\alpha$ p75 (with 95\% confidence interval) in cases (clinical or laboratory progression within 1 year after starting highly active antiretroviral therapy) and controls (who did not progress within the first year of HAART), modeling using a linear mixed model, ANRS CO8 APROCO-COPILOTE.

Our findings may be explained by the relations between the TNF system and HIV replication. HIV enhances TNF- $\alpha$ production in various cells and, in turn, this activation induces activation of NF- $\kappa \mathrm{B}$, enhancing HIV replication through an amplification circle. ${ }^{34-36}$ Therefore, the increased activation of the TNF system may be either the cause or the result of an increase of HIV-RNA. It has already been suggested that persistent activation of the TNF system may be involved in treatment failure ${ }^{7}$ and that decreased TNF activity may lead to low-grade viral replication in HAARTtreated patients. ${ }^{5,37}$ In this context the impact of antiinflammatory or anti-TNF drugs might be of interest; thalidomide induced, in vitro, a decrease of HIV type 1 replication in human macrophages, but its use for countering oral esophageal ulcers was not associated with a reduction of plasma levels of HIV RNA, TNF- $\alpha$, or its soluble receptors. ${ }^{38-40}$ Conversely, pentoxiphylline therapy improved constitutional manifestations and sustained CD4 counts among asymptomatic HIVinfected individuals. ${ }^{41}$

If sR-TNF- $\alpha$ p75 plasma levels reflect the activation of the TNF system, we may hypothesize that it also reflects an activity of HIV disease that is not explored by the measurement of plasma HIV RNA: in this way activation of inflammatory pathways has recently been considered as having a potential deleterious impact on morbidity in HIV-infected patients. ${ }^{42}$ Optimization of antiretroviral therapy might then be considered in patients with high sR-TN $\alpha$ p75 and low HIV-RNA plasma levels and, conversely, therapeutic reductions could be assessed in patients with low HIV-RNA and low sR-TNF- $\alpha$ p75 plasma levels.

$\mathrm{CD}^{+}{ }^{+}$cell count is the only immune marker routinely measured in HIV-infected subjects, but its evolution under treatment is slow and widely varies among HAART-treated patients. An increase of plasma soluble markers may be an earlier marker of poor progression by preceding the increase of HIV RNA and the decrease of CD4 ${ }^{+}$lymphocyte counts for several months. ${ }^{43}$ Therefore, our results suggest that plasma sR-TNF- $\alpha$ p 75 could be an early marker for treatment failure, allowing treatment adaptations as soon as possible. Moreover, $\mathrm{CD} 4^{+}$cell count does not reflect the activation status of the immune system, although it is of particular interest in the case of discordant immunovirological responses to treatment, especially when the $\mathrm{CD}^{+}$count and plasma HIV1 RNA are both low. Measurement of plasma sR-TNF- $\alpha$ p75 might then be an earlier and additive marker of the immunological effect of antiretroviral therapy. If the prognostic value of plasma sR-TNF- $\alpha$ p75 level to predict failure of HAART is confirmed by further evaluations, the use of this immune marker should be considered during the development of new antiretrovirals or immune therapies.

\section{Appendix}

\section{APROCO-COPILOTE ANRS CO8 Study Group}

Scientific Committee: Steering Committee: Principal Investigators: C. Leport, F. Raffi; Methodology: G. Chêne, R. Salamon; Social Sciences: J-P. Moatti, J. Pierret, B. Spire; Virology: F. Brun-Vézinet, H. Fleury, B. Masquelier; Pharmacology: G. Peytavin, R. Garraffo; Other members: D. Costagliola, P. Dellamonica, C. Katlama, L. Meyer, D. Salmon, A. Sobel ; Events Validation Committee: L. Cuzin, M. Dupon, X. Duval, V. Le Moing, B. Marchou, T. May, P. Morlat, C. Rabaud, A. Waldner-Combernoux; Project Coordination: F. Collin-Filleul; ANRS Representatives: Nadine Job-Spira, Marcia Trumeau; Observer: M. Garré; Clinical Research Group: V. Le Moing, C. Lewden.

\section{Data monitoring and statistical analysis}

C. Alfaro, S. Boucherit, AD Bouhnik, C. Brunet-François, M.P. Carrieri, M. Courcoul, F. Couturier, J.L. Ecobichon, M. François, V. Guiyedi, L. Iordache. P. Kurkdji, JP Legrand, S. Martiren, E. Pereira, M. Préau, C. Protopopescu, C. Roy, J. Surzyn, A. Taieb, V. Villes, H. Zouari.

Promotion: Agence Nationale de Recherches sur le Sida et les hépatites virales (ANRS, Action Coordonnée no. 7).

Other Supports: Collège des Universitaires de Maladies Infectieuses et Tropicales (CMIT ex APPIT), Sidaction Ensemble contre le Sida, et laboratoires: Abbott, Boehringer-Ingelheim, Bristol-Myers Squibb, Glaxo-SmithKline, Roche.

Clinical Centers (coordinators): Amiens (Pr. J.L. Schmit), Angers (Dr. J.M. Chennebault), Belfort (Dr. J.P. Faller), Besançon (Pr. J.L. Dupond, Dr. J.M. Estavoyer, Dr. Drobachef), Bobigny (Pr. O. Bouchaud), Bordeaux (Pr. M. Dupon, Pr. Longy-Boursier, Pr. P. Morlat, Pr. J.M. Ragnaud), Bourg-enBresse (Dr. P. Granier), Brest (Pr. M. Garré), Caen (Pr. R. Verdon), Compiègne (Dr. D. Merrien), Corbeil Essonnes (Dr. A. Devidas), Créteil (Pr. A. Sobel), Dijon (Pr. H. Portier), Garches (Pr. C. Perronne), Lagny (Dr. P. Lagarde), Libourne (Dr. J. Ceccaldi), Lyon (Pr. D. Peyramond), Meaux (Dr. C. Allard), Montpellier (Pr. J. Reynes), Nancy (Pr. T. May), Nantes (Pr. F. Raffi), Nice (Pr. J.G. Fuzibet, Pr. P. Dellamonica), Orléans (Dr. P. Arsac), Paris (Pr. E. Bouvet, Pr. F. Bricaire, Pr. P. Bergmann, Pr. J. Cabane, Dr. J. Monsonego, Pr. P.M. Girard, Pr. L. Guillevin, Pr. S. Herson, Pr. C. Leport, Pr. MC. Meyohas, Pr. J.M. Molina, Pr. G. Pialoux, Pr D. 
Salmon), Poitiers (Pr. B. Becq-Giraudon), Reims (Pr. R. Jaussaud), Rennes (Pr. C. Michelet), Saint-Etienne (Pr. F. Lucht), Saint-Mandé (Pr. T. Debord), Strasbourg (Pr. J.M. Lang), Toulon (Dr. J.P. De Jaureguiberry), Toulouse (Pr. B. Marchou), Tours (Pr. J.M. Besnier).

\section{Acknowledgments}

The authors wish to acknowledge the work of Geneviève Chêne for study design and helpful discussion and of Cécile Droz and Céline Aubenque for their technical assistance. The authors acknowledge the sponsorship of the French Research Agency for Research on AIDS (Agence Nationale de Recherches sur le Sida, ANRS, Action Coordonnée no. 7), financial support from the ANRS, and support from the Collège des Enseignants de Maladies Infectieuses et Tropicales (CMIT). Support for this specific study was provided by a grant from Paris 7 University (FAC-SIDA) for the measurements of plasma levels of immune markers

\section{Disclosure Statement}

Support was provided by associated pharmaceutical companies: Abbott, Boehringer-Ingelheim, Bristol-Myers Squibb, Glaxo-SmithKline, Merck Sharp and Dohme, and Roche.

\section{References}

1. Godfried MH, van der Poll T, Weverling GJ, et al.: Soluble receptors for tumor necrosis factor as predictors of progression to AIDS in asymptomatic human immunodeficiency virus type 1 infection. J Infect Dis 1994;169:739-745.

2. Godfried MH, van der Poll T, Mulder JW, et al.: Soluble tumor necrosis factor receptors as surrogate markers for the assessment of zidovudine treatment in asymptomatic HIV1 infection. J Acquir Immune Defic Syndr Human Retrovirol 1995;10:531-539.

3. Fahey J, Taylor J, Detels R, et al.: The prognostic value of cellular and serologic markers in infection with human immunodeficiency virus type 1. N Engl J Med 1990;322:166-172.

4. Zangerle R, Steinhuber S, Sarcletti M, et al:: Serum HIV1 RNA levels compared to soluble markers of immune activation to predict disease progression in HIV-1-infected individuals. Int Arch Allergy Immunol 1998;116: 228-239.

5. Aukrust P, Muller F, Lien E, et al.: Tumor necrosis factor (TNF) system levels in human immunodeficiency virus-infected patients during highly active antiretroviral therapy: Persistent TNF activation is associated with virologic and immunologic treatment failure. I Infect Dis 1999;179:74-82.

6. Saves M, Morlat P, Chene G, et al.: Prognostic value of plasma markers of immune activation in patients with advanced HIV disease treated by combination antiretroviral therapy. Clin Immunol 2001;99:347-352.

7. Stein DS, Lyles RH, Graham NM, et al.: Predicting clinical progression or death in subjects with early-stage human immunodeficiency virus (HIV) infection: A comparative analysis of quantification of HIV RNA, soluble tumor necrosis factor type II receptors, neopterin, and beta2-microglobulin. Multicenter AIDS Cohort Study. J Infect Dis 1997;176: 1161-1167.

8. Bonnet F, Saves M, Morlat PH, et al.: Correlations of soluble interleukin-2 and tumor necrosis factor type II receptors with immunologic and virologic responses under HAART. I Clin Immunol 2002;22:75-82.
9. Prescott S, Zimmerman G, and McIntyre T: Platelet-activating factor. J Biol Chem 1996;268:17381-17384.

10. Kravchenko V, Pan Z, Han J, Herbert J, Ulevitch R, and Ye R: Platelet-activating factor induces NF-kappa B activation through a G protein-coupled pathway. I Biol Chem 1995; 270:14928-14934.

11. Le Naour R, Clayette $P$, Henin $Y$, et al.: Infection of human macrophages with an endogenous tumour necrosis factoralpha (TNF-alpha)-independent human immunodeficiency virus type 1 isolate is unresponsive to the TNF-alpha synthesis inhibitor RP 55778. J Gen Virol 1994;75:1379-1388.

12. Nakamura M, Honda Z, Izumi $T$, et al.: Molecular cloning and expression of platelet-activating factor receptor from human leukocytes. J Biol Chem 1991;266:20400-20405.

13. Tjoelker L and Stafforini D: Platelet-activating factor acetylhydrolases in health and disease. Biochem Biophys Acta 2000;1488:102-123.

14. Pietarinen-Runtti P, Lakari E, Raivio K, and Kinnula V: Expression of antioxidant enzymes in human inflammatory cells. Am J Physiol Cell Physiol 2000;278:118-125.

15. Herzenberg L, De Rosa S, Dubs J, et al:: Glutathione deficiency is associated with impaired survival in HIV disease. Proc Natl Acad Sci USA 1997;94:1967-1972.

16. Garaci E, Palamara A, Ciriolo M, et al.: Intracellular GSH content and HIV replication in human macrophages. J Leukoc Biol 1997;62:54-59.

17. Staal F, Roederer M, and Herzenberg L: Intracellular thiols regulate activation of nuclear factor kappa B and transcription of human immunodeficiency virus. Proc Natl Acad Sci USA 1990;87:9943-9947.

18. Le Moing V, Thiébaut R, Chêne G, et al.: Plasma HIV RNA as predictor of long-term increase of CD4+ cell counts in human immunodeficiency virus-infected patients initiating a protease-inhibitor containing regimen. I Infect Dis 2002; 185:471-480.

19. Centers for Disease Control and Prevention: 1993 revised classification system for HIV infection and expanded surveillance case definition for AIDS among adolescents and adults. MMWR Morb Mortal Wkly Rep 1992;41:1-19.

20. Hughes MD, Johnson VA, Hirsch MS, et al.: Monitoring plasma HIV-1 RNA levels in addition to CD4+ lymphocyte count improves assessment of antiretroviral therapeutic response. ACTG 241 Protocol Virology Substudy Team. Ann Intern Med 1997;126:929-938.

21. Mellors J, Munoz A, Giorgi J, et al.: Plasma viral load and CD4+ lymphocytes as prognostic markers of HIV-1 infection. Ann Intern Med 1997;126:946-954.

22. Graham NM: The role of immunologic and viral markers in predicting clinical outcome in HIV infection. AIDS 1996; 10:S21-25.

23. Engelberts I, Moller A, Schoen G, van der Linden C, and Buurman W: Evaluation of measurement of human TNF in plasma by ELISA. Lymphok Cytok Res 1991;10:69-76.

24. Aderka D, Engelmann H, Maor Y, Brakebusch C, and Wallach D: Stabilization of the bioactivity of tumor necrosis factor by its soluble receptors. I Exp Med 1992;175:323-329.

25. Kalinkovich A, Geleziunas R, Kemper O, et al.: Increased soluble tumor necrosis factor receptor expression and release by human immunodeficiency virus type 1 infection. I Interferon Cytokine Res 1995;15:749-757.

26. Benito JM, Lopez M, Lozano S, Martinez P, Gonzales-Lahoz J, and Soriano V: CD38 expression on CD8 T lymphocytes as a marker of residual virus replication in chronically HIVinfected patients receiving antiretroviral therapy. AIDS Res Hum Retroviruses 2004;20:227-233. 
27. Ondoa P, Koblavi-Dème S, Borget MY, Nolan ML, Nkengasong JN, and Kestens L: Assesment of CD8 T cell immune activation markers to monitor response to antiretroviral therapy among HIV-1 infected patients in Côte d'Ivoire. Clin Exp Immunol 2005;140:138-148.

28. Steel A, John L, Shamji MH, et al.: CD 38 expression on CD8 $\mathrm{T}$ cells has a weak association with CD4 T-cell recovery and is a poor marker of viral replication in HIV1-infected patients on antiretroviral therapy HIV Med 2008;9:118-125.

29. Wang C, Wen T, Routy J-P, Bernard NF, Sekaly RP, and Watts TH: 4-1BBL induces TNF receptor-associated factor 1dependent Bim modulation in human T cells and is a critical component in the costimulation-dependent rescue of functionally impaired HIV-specific CD8 T cells. J Immunol 2007;179:8252-8263.

30. Herbein G and Khan KA: Is HIV infection a TNF receptor signalling-driven disease? Trends Immunol 2008;29:61-67.

31. Pérez-Casanova A, Husain K, Noel RJ Jr, Rivera-Amill V, and Kumar A: Interaction of SIV/SHIV infection and morphine on plasma oxidant/antioxidant balance in macaque. Mol Cell Biochem 2008;308:169-175.

32. Jariwalla RJ, Lalezari J, Cenko D, Mansour SE, Kumar A, Gangapurkar B, and Nakamura D: Restoration of blood total glutathione status and lymphocyte function following lipoic acid supplementation in patients with HIV infection. J Altern Complement Med 2008;14:139-146.

33. Stephensen CB, Marquis GS, Douglas SD, Kruzich LA, and Wilson CM: Glutathione, glutathione peroxidase, and selenium status in HIV-positive and HIV-negative adolescents and young adults. Am J Clin Nutr 2007;85:173-181.

34. Merrill JE, Koyanagi Y, and Chen IS: Interleukin-1 and tumor necrosis factor alpha can be induced from mononuclear phagocytes by human immunodeficiency virus type 1 binding to the CD4 receptor. J Virol 1989;63:4404-4408.

35. Merrill JE, Koyanagi Y, Zack J, Thomas L, Martin F, and Chen IS: Induction of interleukin-1 and tumor necrosis factor alpha in brain cultures by human immunodeficiency virus type 1. J Virol 1992;66:2217-2225.

36. Westendorp MO, Shatrov VA, Schulze-Osthoff K, et al.: HIV1 Tat potentiates TNF-induced NF-kappa B activation and cytotoxicity by altering the cellular redox state. EMBO J 1995; 14:546-554.

37. Kedzierska K and Crowe SM: Cytokines and HIV 1: Interactions and clinical implications. Antiviral Chem Chemother 2001;12:133-150.

38. La Maestra L, Zaninoni A, Marriott JB, Lazzarin A, Dalgleish AG, and Barcellini W: The thalidomide analogue CC-3052 inhibits HIV-1 and tumour necrosis factor-alpha (TNF-alpha) expression in acutely and chronically infected cells in vitro. Clin Exp Immunol 2000;119:123-129.

39. Moreira A, Corral L, Ye W, et al.: Thalidomide and thalidomide analogs reduce HIV type 1 replication in human macrophages in vitro. AIDS Res Hum Retroviruses 1997;13:857863.

40. Jacobson JM, Greenspan JS, Spritzler J, et al.: Thalidomide for the treatment of oral aphthous ulcers in patients with human immunodeficiency virus infection. National Institute of Allergy and Infectious Diseases AIDS Clinical Trials Group. N Engl J Med 1997;336:1487-1493.

41. Wanchu A, Bhatnagar A, Bambery P, et al.: Prevention of opportunistic infections in HIV infection by pentoxyphylline. Indian J Med Res 2006;124:705-708.

42. Kuller L and SMART Study: Elevated levels of interleukin6 and D-dimer are associated with an increased risk of death in patents with HIV. 15th Conference on Retroviruses and Opportunistic Infections, Boston, February 3-6, 2008, Abstract 139.

43. Salazar-Gonzalez JF, Martinez-Maza O, Aziz N, et al.: Relationship of plasma HIV-RNA levels and levels of TNF-alpha and immune activation products in HIV infection. Clin Immunol Immunopathol 1997;84:36-45.

Address reprint requests to: Philippe Morlat Hôpital Saint-André 1 rue Jean Burguet 33076 Bordeaux cedex, France

E-mail: philippe.morlat@chu-bordeaux.fr 


\section{This article has been cited by:}

1. James D Neaton, Jacqueline Neuhaus, Sean Emery. 2010. Soluble biomarkers and morbidity and mortality among people infected with HIV: summary of published reports from 1997 to 2010. Current Opinion in HIV and AIDS 5:6, 480-490. [CrossRef]

2. Neifi HS Deghaide, Maria de LV Rodrigues, Erick C Castelli, Celso T Mendes-Junior, José FC Figueiredo, Eduardo A Donadi. 2009. Tumor necrosis factor region polymorphisms are associated with AIDS and with cytomegalovirus retinitis. AIDS 23:13, 1641-1647. [CrossRef] 